\title{
Infestation of Weed Species in Pre-Planting of Soybean in SuCCESSION TO WINTER CROPS ${ }^{1}$
}

\author{
Infestação de Espécies de Plantas Daninhas em Pré-Plantio de Soja em Sistema de Sucessão \\ a Culturas de Inverno
}
CONCENÇO, G. ${ }^{2}$, SILVA, C.J. ${ }^{3}$, TOMAZI, M. ${ }^{4}$, CORREIA, I.V.T. ${ }^{5}$, SOUZA, N.C.D.S. ${ }^{5}$, and ANDRES, A. ${ }^{6}$

\begin{abstract}
This study aimed to evaluate different crops and plant species planted after soybeans for one year, in terms of their potential to inhibit the occurrence of weed species. The following crops that were planted as second crop after soybeans were evaluated: (1) corn (Zea mays) planted at spacing of $90 \mathrm{~cm}$ between rows, intercropped with Brachiaria ruziziensis in the inter-rows; (2) sunflower (Helianthus annuus); (3) crambe (Crambe abyssinica); (4) radish (Raphanus sativus); (5) rapeseed (Brassica napus); and (6) winter fallow-no plantation after soybeans. Phytosociological characterization of weed species was carried out at the pre-planting of soybeans in the following cropping season. Estimations of relative abundance, relative frequence, relative dominance and Importance Value Index were made for each species present. Areas were also intra-characterized by the diversity coefficients of Simpson and modified Shannon-Weiner, and areas were compared using the Jaccard similarity coefficient for presence-only, by multivariate cluster analysis. In the short-term (a single cropping season), cultivation of winter crops do contribute for lower occurrence of weed species at the pre-planting of soybeans on the subsequent cropping season. The suppressive effects depend both on the species grown in the winter and in the amount of straw left on the soil by these winter crops. Radish was more efficient in inhibiting the occurrence of weed species and rapeseed showed composition of infestation similar to that observed at the area under fallow.
\end{abstract}

Keywords: corn, sunflower, radish, crambe, rapeseed, phytosociology.

\begin{abstract}
RESUMO - Objetivou-se com este estudo avaliar distintas espécies vegetais cultivadas na segunda safra, quanto ao seu potencial de inibir a ocorrência de espécies daninhas. As seguintes culturas foram avaliadas na segunda safra após soja: (1) milho (Zea mays) com espaçamento entre linhas de $90 \mathrm{~cm}$; (2) girassol (Helianthus annuus); (3) crambe (Crambe abyssinica); (4) nabo forrageiro (Raphanus sativus); (5) canola (Brassica napus); e (6) pousio sem plantio de inverno em sucessão à soja. A caracterização fitossociológica das espécies daninhas foi feita no pré-plantio da safra de soja subsequente. Estimativas de abundância, frequência e dominância relativas, bem como do valor de importância, foram obtidas para cada espécie em cada área. As áreas foram intracaracterizadas pelos coeficientes de diversidade de Simpson e de Shannon-Weiner modificado e comparadas pelo coeficiente binário de similaridade de Jaccard, por análise multivariada de agrupamento. No curto prazo (um ano de distintos cultivos), o uso de oleaginosas de inverno contribuiu para a menor infestação por plantas daninhas na soja em sucessão, e os efeitos supressivos dependem tanto da espécie cultivada no inverno quanto do volume de palhada residual deixada por essa cultura. O nabo forrageiro foi o mais eficiente em inibir a ocorrência de espécies daninhas, e a canola apresentou composição da infestação similar à observada na área de pousio.
\end{abstract}

Palavras-chave: milho, girassol, crambe, nabo forrageiro, canola, fitossociologia.

1 Recebido para publicação em 8.8.2012 e aprovado em 9.12.2012

2 Ph.D., Weed Science, Brazilian Company of Agricultural Research - EMBRAPA, Western Agriculture Research Center - CPAO, Dourados city, Mato Grosso do Sul State, Brazil, <germani.concenco@embrapa.br>; ${ }^{3}$ Ph.D., Agro-Energy, EMBRAPA - CPAO, <cesar.silva@embrapa.br>; ${ }^{4}$ Ph.D., Soil Science, EMBRAPA - CPAO, <michely.tomazi@embrapa.br>; ${ }^{5}$ Undergraduate students in Agronomy, trainees, EMBRAPA - CPAO; ${ }^{6}$ M.Sc., Weed Science, Embrapa Temperate Agriculture, BR 392, Km 78, $96001-970$ Pelotas, Brazil, D.Sc., student at Dipartimento di Agronomia, Selvicoltura e Gestione del Territorio, University of Torino, Via L. da Vinci 44, 10095 Grugliasco, TO, Italy.

Planta Daninha, Viçosa-MG, v. 31, n. 3, p. 551-558, 2013 


\section{INTRODUCTION}

Soybean is one of the leading economical crops grown in Brazil, with about 24 million hectare planted in the 2010/2011 cropping season (CONAB, 2011). Soybean yields in Brazil had significantly increased in the last decades, and current the Brazilian average yield is $3,047 \mathrm{~kg} \mathrm{ha}^{-1}$, superior to the NorthAmerican and Argentine averages in the corresponding cropping season (Silva Neto, 2011). Among the factors which limit crop yield, the occurrence of weed species can be highlighted as one of the most relevant facts (Vollmann et al., 2010).

Recent GMO technologies have aimed to employ herbicide resistance to soybean varieties, and have drastically reduced the infestation of weed species in most fields with such technologies. However, lack of Government regulation and Farmer's mismanagement of such technologies led to the selection of weed species tolerant or resistant to the herbicides applied with these technologies (Trezzi et al., 2007). The RoundupReady ${ }^{\circledR}$ soybean was widely used in Brazil, and currently Conyza bonariensis, C. canadensis, C. sumatrensis, Digitaria insularis, and Lolium multiflorum are resistant to glyphosate, due to its extensive and almost uncontrolled use in RoundupReady soybean (Heap, 2012). This abuse, moreover, resulted in the selection of weed species naturally more tolerant to glyphosate, namely Ipomoea spp., Richardia brasiliensis and Commelina benghalensis, among others.

This fact has made researchers and companies retreat from the excessive reliability in GMO crops and has provided new possibilities to researches that regard integrated weeds management and integrated cropping systems (Cruz et al., 2009; Bianchi et al., 2011; Agromundo, 2012). Researchers also started to notice that it is important to know the key traits of weed plants intended to be eliminated from the system, in order to develop management techniques that are efficient to the controlling of such species. Phytosociological surveys started to gain relevance at the weed Science field (Contato, 2007; Concenço et al., 2011; Rossol et al., 2011).

Planta Daninha, Viçosa-MG, v. 31, n. 3, p. 551-558, 2013
One of the main management practices which contribute to the reduction in weeds infestation is the continuous maintenance of straw on the soil surface (Meschede et al., 2007; Gomes Junior \& Christoffoleti, 2008), which limits weeds access to light. In addition, some plant species produce chemicals which usually exudates to the soil through the root system, inhibiting germination and/or growth of other plant species. This phenomenon is called Allelopathy (Inderjit \& Mallik, 2002).

The intercrop of corn second crop (planted after soybeans) with forages was developed to allow the maintenance in the area of a bold layer of straw after corn is harvested (Ceccon, 2008), thus soil would not be exposed until soybeans were planted in the next cropping season. Winter crops are also alternatives to keep the soil covered in most of the period when the crop is not present. In addition, some oilseed plant species suitable to be grown in the winter, like radish (Raphanus sativus), crambe (Crambe abyssinica) and rapeseed (Brassica napus) may be useful for producing biofuels (Chammoun, 2009) and its potential to suppress the occurrence of weed species in areas where these are rotated with soybeans would be a highly desired side-effect.

This study aimed to evaluate different crops and plant species planted after soybeans for one year, in terms of their potential to inhibit the occurrence of weed species.

\section{MATERIAL AND METHODS}

The experiment was installed under field conditions at Embrapa Western Region Agriculture, Dourados, Mato Grosso do Sul State, Brazil, located at geographical coordinates $22^{\circ} 16^{\prime} \mathrm{S}$ and $54^{\circ} 49^{\prime} \mathrm{W}$ at $408 \mathrm{~m}$ above sea level. The trial was composed by large growing areas $(12 \times 120 \mathrm{~m})$ where ten sub samples were taken in each evaluation. The source of variation, for the data which require that, was obtained from sub-samplings inside the main plot.

For the last two years (2009/10 and 2010/ 11), soybeans were planted in the no-till system in all the area of the experiment by October/ November, harvested in February/March of the following year. After soybeans in 2011, areas were planted with one of the following 
crops, which comprised the "treatments": (1) corn planted at spacing of $90 \mathrm{~cm}$ between rows, intercropped with Brachiaria ruziziensis in the inter-rows; (2) sunflower (Helianthus annuus); (3) crambe (Crambe abyssinica); (4) radish (Raphanus sativus); (5) rapeseed (Brassica napus); and (6) winter fallow - no plantation after soybeans.

Corn second crop was planted in March $7^{\text {th }}$, 2011 with $0.9 \mathrm{~m}$ of row spacing and 5 plants $\mathrm{m}^{-1}$ in the row. Brachiaria ruziziensis was planted in the interrows of corn in intercrop. Sunflower was planted in March $7^{\text {th }} 2011$ in rows spaced in $0.45 \mathrm{~m}$, with three plants per meter in the row. The winter oilseed crops (crambe, radish, rapeseed) were planted in April 27 2011 in rows spaced in $0.4 \mathrm{~m}$, at plant densities of 54 , 32 and 25 plants $\mathrm{m}^{-1}$ in the row, respectively for crambe, radish and rapeseed. For the treatments corn+ruziziensis, sunflower, crambe, radish and rapeseed fertilization was accomplished by applying $347 \mathrm{~kg} \mathrm{ha}^{-1}$ of NPK 08-20-20 in the seeding furrow by planting.

A post-emergence nitrogen application was made 45 days after emergence in the intercrop corn+ruziziensis and in the sunflower, by applying 36 and $30 \mathrm{~kg} \mathrm{ha}^{-1}$ of $\mathrm{N}$, respectively. In the areas grown with the winter oilseed crops no further management (fertilization or pest control) was accomplished.

The amount of straw (in terms of dry mass) and its resultant percentage of soil covered were evaluated right after the harvest of winter crops (in August/September). In addition, the number of plants of weed species and its resulting dry mass accumulated were evaluated at the pre-planting of soybean, in October 2011. All data was verified for normality by the Shapiro-Wilk test and submitted to the LSD-test. Data for these parameters were presented in histograms as a function of means and standard errors.

Phytosociological characterization of weed species emerged from soil seed bank was also carried out for all areas, at the preplanting of soybeans. For that, the Random Quadrats method (Barbour et al., 1998) was used and 10 areas of $0.50 \times 0.50 \mathrm{~cm}$ in each management system were sampled. All the emerged seedlings inside the square were identified by species, collected and stored in paper bags in each sampled area, and then dried in oven with continuous air circulation for posterior dry mass determination.

Estimations of relative abundance (based on number of individuals), relative frequency (based on the distribution of the species in the area) and relative dominance (based on the ability of each species to accumulate dry mass) were done for each species present. The Importance Value Index (I.V.I.), which ranks species in terms of importance within the studied area, was also determined (Pandeya et al., 1968; Barbour et al., 1998). Areas were also intra-characterized by the diversity coefficients of Simpson (D) and modified Shannon-Weiner (H') (Barbour et al., 1998). After these analyses, areas were compared by Jaccard's presence-only similarity coefficient (Barbour et al., 1998) in a way to estimate the current degree of weeds similarity between areas after two years of different winter cropping.

Based on the Jaccard's coefficient, areas were grouped by cluster analysis considering the qualitative trait only (presence or absence of the species), according to the dissimilarities obtained from the inverse of Jaccard's similarity matrix. Hierarchical grouping was determined from the distance matrix (dissimilarities) (Barbour et al., 1998) by using the Unweighted Pair Group Method with Arithmethic Mean (UPGMA) method (Sneath \& Sokal, 1973). Grouping validation was accomplished by the cophenetic correlation coefficient, using the Pearson linear correlation between the cophenetic matrix and the original matrix of distances (Sokal \& Rohlf, 1962).

All analyses were ran under the $R$ Statistical Environment (R-development, 2012), using functions made available by the following additional packages: base, graphics, vegan, Hmisc, cluster and ExpDes. All formulas and procedures, both at sampling and description of the areas, as well as at species clustering, followed the requirements suggested by Barbour et al. (1998) for synecological analyses.

\section{RESULTS AND DISCUSSION}

The amount of post-harvest dry mass, deposited on the soil surface by the different crops, differed according to the LSD test at 5\% 
probability (Figure 1). The higher absolute deposited amount of straw was obtained at the area where corn was intercropped with Brachiaria, and in general terms, smaller volumes of straw were found where crambe was grown and in the winter fallow area (Figure 1).

The intercrop of corn with Brachiaria is one of the most widely used strategies in Western Brazil to allow keeping a mulching on the soil throughout the winter (Ceccon, 2008). After corn second crop is harvested (by May/June), Brachiaria receives adequate amounts of sunlight, thus producing fresh mass, enough to cover most of the soil and prevent weeds access to light (Rossol et al., 2011). In addition, sunflower presented a significant volume of dry mass at the soil surface after harvest when compared to the other crops. But even producing high amounts of straw, sunflower dry mass does not present good distribution on the soil, because most of the dry mass is concentrated in the bold stems with smaller occurrence of leaves.

The percentage of the soil surface covered by straw resulting from the winter crops, is shown in Figure 2. There was a direct relationship between the volume of dry mass produced by each crop/management (Figure 1), and the respective percentage of soil covered by this straw (Figure 2) (Pearson correlation $\left.=82.5 \%{ }^{*}\right)$. On the other hand, there were no significant relationships neither between the percentage of soil covered by the straw and number of plants of weed species (Pearson $\left.=33.4 \%{ }^{\mathrm{ns}}\right)$, nor between soil covered and dry mass of weeds $\left(\right.$ Pearson $\left.=46.7 \%{ }^{\text {ns }}\right)$.

The number of weed plants differed among treatments, according to the LSD test at 5\% probability, and the highest number of individuals was found at the areas with rapeseed and winter fallow (Figure 3). The areas with intercrop corn/Brachiaria, sunflower, crambe and radish presented similar number of individuals of weed species, averaging 24.7 plants $\mathrm{m}^{-2}$. While the areas of rapeseed and fallow presented in average 54.8 plants $\mathrm{m}^{-2}$ (Figure 3). This represents an increase in infestation (based in the number of individuals) of $121 \%$ at the latter areas, in comparison to the average of the former group.

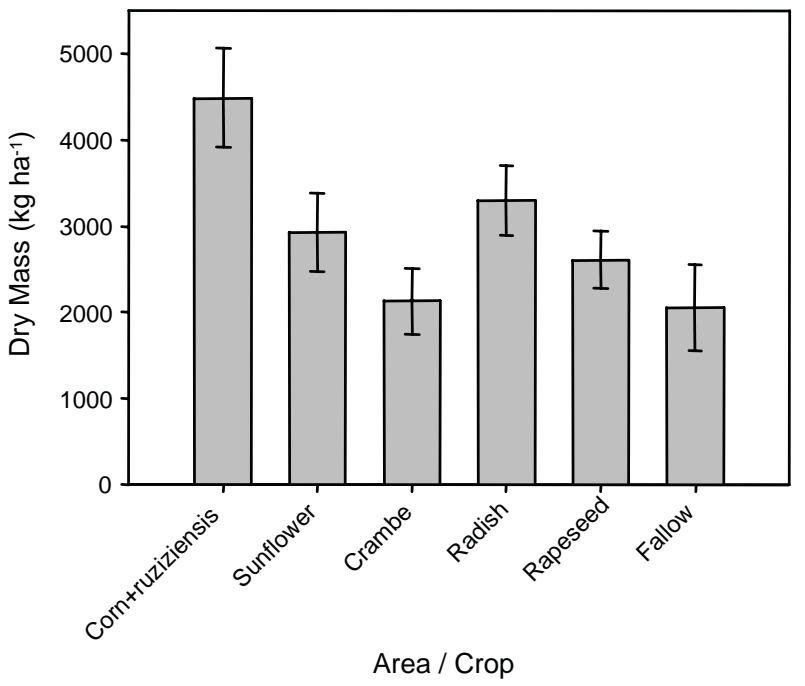

Figure 1 - Dry mass deposited at the soil surface by the different winter crops, evaluated immediately after the harvesting of winter crops. $\mathrm{CV}=24.8 \%$; Shapiro-Wilk $=0.23^{\mathrm{N}}$. Embrapa Western Region Agriculture, Dourados-MS, Brazil, 2012.

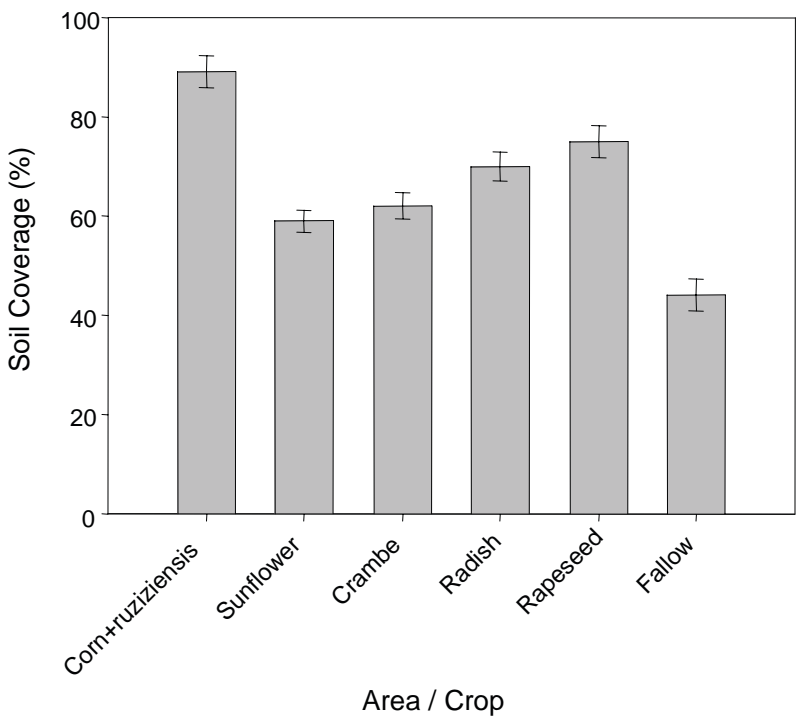

Figure 2 - Soil coverage (\%) by winter crop residues, evaluated immediately after the harvesting of winter crops. $\mathrm{CV}=12.9 \%$; Shapiro-Wilk $=0.44^{\mathrm{N}}$. Embrapa Western Region Agriculture, Dourados-MS, Brazil, 2012.

The correlation analysis of Pearson showed that the amount of dry mass left on soil by different crops had a relation of $-58 \%$ ns with the number of individuals of weeds species present at the areas with the preplanting of soybeans. This lack of significant correlation probably means that the inhibition of growth and seeds production of weed species 


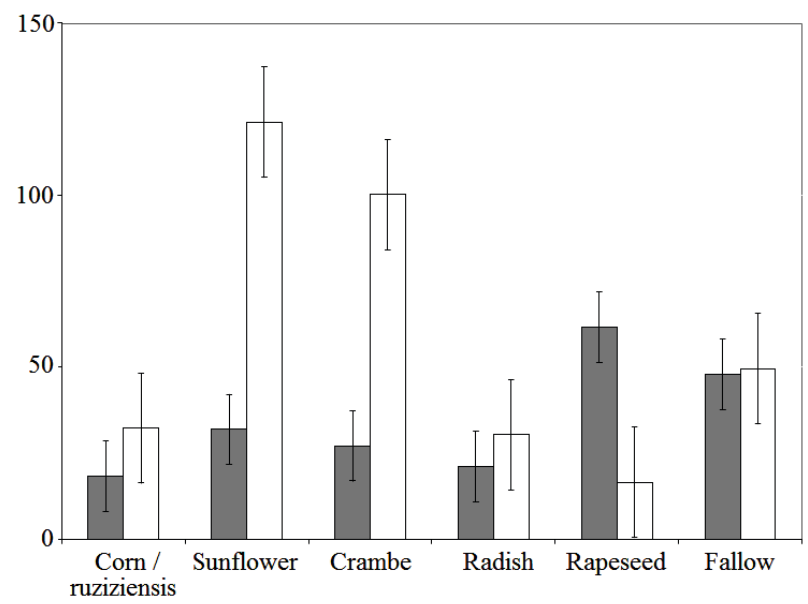

Figure 3 - Number of plants of weed species per square meter $(\square)$ and its corresponding dry mass accumulated $(\square)$ in $\mathrm{g} \mathrm{m}^{-2}$ at the pre-planting of soybeans following different winter crops. $\mathrm{CV}=32.4 \%$; Shapiro-Wilk $=0.22^{\mathrm{N}}$. Embrapa Western Region Agriculture, Dourados-MS, Brazil, 2012.

by the winter crops is more important than the factor "amount of straw left" by the different winter crops. The dry mass accumulated by weed was also significant, but on the other hand, was higher at the areas grown with sunflower and crambe (Figure 3). Pearson analysis reported $-33 \%$ ns of correlation between the amount of straw left by winter crops at the soil surface by harvest, and the dry mass of weed species at pre-planting of soybean.

The phytosociological analysis for the area with corn intercropped with Brachiaria, highlighted Amaranthus hybridus and Raphanus raphanistrum as the most abundant weed species, A. hybridus as the most frequent one and A. hybridus and Richardia brasiliensis as the most dominant weed species. As a result, species were ranked as follows according to their Importance Value Index: A. hybridus (29.70\%), R. brasiliensis $(21.30 \%), R$. sativus (17.73\%) and L. virginicum (14.83\%). The remainder of the species (data not shown) was responsible for only $16.45 \%$ of the infestation at that area (Table 1). A. hybridus is one of the most important weed species in agricultural areas, and plants from this species exhibit a high phenotypic plasticity and genetic variability, and they easily adapt to a multitude of agrestal and ruderal habitats; the seeds contribute to a persistent seed bank; they exhibit a variable dormancy and
Table 1 - Phytosociological analysis of weed species in areas submitted to different winter managements. Embrapa Western Region Agriculture, Dourados-MS, Brazil, 2012

\begin{tabular}{|c|c|c|c|c|}
\hline Species & $\mathrm{AB}^{*}$ & $\mathrm{FR}^{*}$ & DO $^{*}$ & IVI $^{*}$ \\
\hline & \multicolumn{4}{|c|}{ Corn $+U$. ruziziensis } \\
\hline A. hybridus & 30,43 & 23,81 & 34,86 & 29,70 \\
\hline R. brasiliensis & 17,39 & 19,05 & 27,46 & 21,30 \\
\hline R. raphanistrum & 23,91 & 19,05 & 10,21 & 17,73 \\
\hline L. virginicum & 10,87 & 19,05 & 14,56 & 14,83 \\
\hline \multirow[t]{2}{*}{ Others } & 17,39 & 19,05 & 12,91 & 16,45 \\
\hline & \multicolumn{4}{|c|}{ Sunflower } \\
\hline R. brasiliensis & 48,75 & 27,03 & 45,47 & 40,41 \\
\hline A. hybridus & 20,00 & 18,92 & 21,56 & 20,16 \\
\hline S. rhombifolia & 3,75 & 8,11 & 17,03 & 9,63 \\
\hline E. heterophylla & 5,00 & 8,11 & 1,80 & 4,97 \\
\hline \multirow[t]{2}{*}{ Others } & 22,50 & 37,84 & 14,14 & 24,83 \\
\hline & \multicolumn{4}{|c|}{ Crambe } \\
\hline R. brasiliensis & 37,88 & 12,86 & 43,63 & 31,45 \\
\hline A. hybridus & 18,37 & 5,71 & 33,84 & 19,31 \\
\hline B. pilosa & 3,44 & 4,29 & 5,70 & 4,48 \\
\hline T. paniculatum & 3,44 & 2,86 & 3,27 & 3,19 \\
\hline \multirow[t]{2}{*}{ Others } & 36,87 & 74,29 & 13,56 & 41,57 \\
\hline & \multicolumn{4}{|c|}{ Radish } \\
\hline R. brasiliensis & 41,51 & 30,43 & 40,67 & 37,54 \\
\hline L. virginicum & 30,19 & 13,04 & 10,81 & 18,01 \\
\hline A. hybridus & 13,21 & 26,09 & 14,05 & 17,78 \\
\hline R. repens & 1,89 & 4,35 & 11,80 & 6,01 \\
\hline \multirow[t]{2}{*}{ Others } & 13,21 & 26,09 & 22,66 & 20,65 \\
\hline & \multicolumn{4}{|c|}{ Rapeseed } \\
\hline L. virginicum & 82,47 & 34,78 & 61,28 & 59,51 \\
\hline R. brasiliensis & 12,99 & 34,78 & 22,18 & 23,32 \\
\hline B. pilosa & 0,65 & 4,35 & 8,01 & 4,34 \\
\hline A. hybridus & 1,30 & 8,70 & 1,91 & 3,97 \\
\hline \multirow[t]{2}{*}{ Others } & 2,60 & 17,39 & 6,61 & 8,87 \\
\hline & \multicolumn{4}{|c|}{ Winter Fallow } \\
\hline L. nepetifolia & 32,25 & 10,00 & 20,01 & 20,75 \\
\hline B. pilosa & 17,39 & 10,00 & 18,15 & 15,18 \\
\hline A. hybridus & 21,38 & 12,50 & 5,55 & 13,14 \\
\hline R. brasiliensis & 6,52 & 10,00 & 16,33 & 10,95 \\
\hline Others & 22,46 & 57,50 & 39,97 & 39,98 \\
\hline
\end{tabular}

$* \mathrm{AB}=$ relative abundance $(\%) ; \mathrm{FR}=$ relative frequence $(\%) ; \mathrm{DO}=$ relative dominance $(\%)$ and IVI $=$ importance index value (\%), found according to formulas and procedures described by Barbour et al. (1998).

Planta Daninha, Viçosa-MG v. 31, n. 3, p. 551-558, 2013 
polymorph germination as a result of maternal, genetic and environmental factors; and growth is rapid and plants produce a large number of viable seeds (Costea et al., 2004). In addition, $R$. sativus is among the weed species with high impact on soybean yields (Bianchi et al., 2011).

At the area grown with sunflower, $R$. brasiliensis was identified as the most abundant, frequent and dominant weed species, thus presenting the highest Importance Value Index $(40.41 \%$ of importance in the overall infestation). A. hybridus was ranked in second with IVI $=20.16 \%$, and Sida rhombifolia and Euphorbia heterophylla represented $9.63 \%$ and $4.97 \%$ of the infestation, respectively. Other species totalized $24.83 \%$ of the overall infestation (Table 1). Gomes Junior \& Christoffoleti (2008), when studying weed species most favored under conventional or notill planting systems, reported that the high occurrence of $R$. brasiliensis and $E$. heterophylla in the no-till system, among other species, may be mostly due to the lack of control planning for these species in the crop rotation, than to the cropping system itself.

The area grown with crambe presented $R$. brasiliensis and $A$. hybridus as both the most abundant and dominant weed species; in addition, the former was also highlighted as the most frequent one. This resulted in these species representing $31.45 \%$ and $19.31 \%$ of the overall infestation, respectively. Bidens pilosa and Talinum paniculatum represented a small share of the overall infestation at this area, and several other species (grouped as "others") represented almost half of the overall infestation - with very small importance for each one of these species (data not shown) (Table 1).

In the area grown with radish, $R$. brasiliensis was highlighted as the most abundant, frequent and dominant weed species, L. virginicum was the second most dominant and $A$. hybridus the second most frequent one (Table 1). This resulted in $R$. brasiliensis being responsible for almost $40 \%$ of the overall infestation at this treatment, followed by the two other species, with about $18 \%$ of importance each. The remainder of the species represented around $27 \%$ of the overall infestation in the area grown with radish (Table 1).
Bianchi et al. (2011) highlight the importance of $R$. sativus as weed species when competing with soybean varieties, and identified that some varieties are less affected by competition with this weed species than others. As a plant suppressor, Bettoni et al. (2012) reported no allelopathy of extracts of $R$. sativus on the establishment of Vitis vinifera. On the other hand, Uygur et al. (1990) reported that extracts of $R$. sativus completely inhibited the germination of 4 crop plants and 11 weed species; Inderjit \& Mallik (2002) also highlight some allelopathic effects of this weed species.

Radish (R. Sativus) was able to accumulate higher amounts of dry mass at the soil surface after harvest than crambe (Figure 1), but its ability to suppress the occurrence of weed species (Figure 3) was much higher than what would be usually attributed to the differential dry mass accumulation by these two crops. This higher suppression of occurrence of weed species can be attributed to the allelopathic effect of radish, as previously reported. In addition, the main weed species at the area grown with crambe were also the main weed species observed at the area grown with radish (Table 1), evidencing that the differential weed infestation at these areas was probably due to the inhibition of germination and/or growth of several less important weed species at the area grown with radish.

In the area grown with rapeseed, L. virginicum was highlighted as the most abundant, frequent and dominant weed species, being in addition as frequent as $R$. brasiliensis. The former was responsible for almost $60 \%$ of the overall infestation at the area grown with rapeseed, $R$. brasiliensis represented about $23 \%$ of the overall infestation, and the remainder of the species totalized about $17 \%$ of the infestation (Table 1). The species $L$. virginicum was the most important weed species at the area grown with rapeseed ( $60 \%$ of the total infestation), but represented only about $18 \%$ of the infestation at the neighboring area grown with radish (Table 1). In addition, this species was not noted among the four main weed species occurring at the area grown with crambe. This highlights the unique ability of plants with allelopathic effects to inhibit the occurrence of different weed species - the allelopatic effect of the 
chemical compound exudates will depend on the weed species occurring at the given area (Inderjit \& Mallik, 2002).

At the area grown only with soybeans in the summer, followed by winter fallow, L. nepetifolia and $A$. hybridus were the most abundant ones, and no species could be highlighted neither in terms of frequency of occurrence nor in terms of dominance. The four species identified as the most important ones at the area under fallow presented Importance Value Indexes between 10\% and $20 \%$ each, and the remainder of the species represented about $40 \%$ of the overall infestation.

When the composition of the infestation is compared among areas, it is possible to observe that $B$. pilosa, A. hybridus and $R$. brasiliensis were present among the important weed species respectively in 3, 6 and 6 of the evaluated areas (Table 1); however, their relevance of occurrence was more balanced at the area under fallow. This probably shows that each crop is more efficient in inhibiting specific weed species than others.

The diversity coefficient of Simpson quantifies, in simple terms, the probability of two individuals randomly collected at the same area to be from the same species. The diversity coefficient of Shannon-Weiner, on the other hand, derives from the Theory of the Information and sometimes confuses diversity with richness of species (Barbour et al., 1998). The diversity coefficients of Simpson and Shannon-Weiner showed practically no differentiation among corn+ Brachiaria, sunflower, crambe and radish areas (Table 2). Rapeseed, however, showed a relative imbalance in terms of occurrence of each weed species, determined mostly by the high abundance, frequency and dominance of L. virginicum which was responsible for about $60 \%$ of the infestation at the area grown with rapeseed (Table 1$)$.

The cluster analysis showed the nesting pattern for areas, according to their levels of similarity (Figure 4). The clustering tree obtained by the UPGMA method was validated with cophenetic correlation coefficient equal to $94 \%$. The cluster analysis showed that only the area under fallow and the area where rapeseed was grown in the winter were able to be nested together according to their similarity of occurrence of weed species. The remainder of the areas differed among themselves, at the stated leve1 of $40 \%$ similarity (Figure 4). The cluster analysis was executed considering all weed species identified at each area, and not only the most important ones.

In summary, in the short-term (a single cropping season), cultivation of winter crops do contribute for a lower occurrence of weed species at the pre-planting of soybeans on the subsequent cropping season, and the

Table 2 - Diversity coefficients of Simpson (D) and ShannonWeiner $\left(\mathrm{H}^{\prime}\right)$ for areas submitted to different winter managements. Embrapa Western Region Agriculture, Dourados-MS, Brazil, 2012

\begin{tabular}{|l|c|c|}
\hline \multirow{2}{*}{\multicolumn{1}{|c|}{ Treatment }} & \multicolumn{2}{c|}{ Diversity Index } \\
\cline { 2 - 3 } & $\mathrm{D}$ & $\mathrm{H}^{\prime}$ \\
\hline Corn + ruziziensis & 0,794 & 2,47 \\
\hline Sunflower & 0,713 & 2,63 \\
\hline Crambe & 0,701 & 2,44 \\
\hline Radish & 0,716 & 2,26 \\
\hline Rapeseed & 0,303 & 0,93 \\
\hline Fallow & 0,682 & 2,25 \\
\hline
\end{tabular}

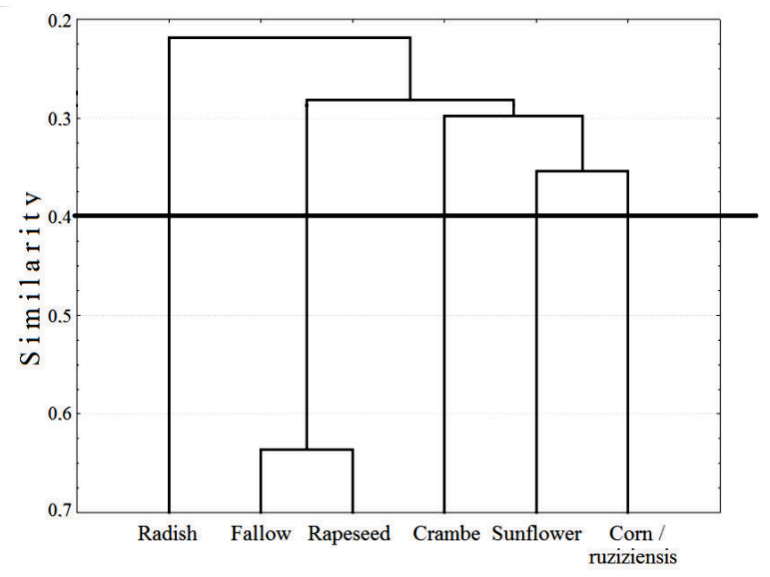

Figure 4 - Cluster analysis of weed species occurrence similarity in areas submitted to different winter managements for two years. Distances were found using the Jaccard's coefficient; grouping was established based on the UPGMA method. Embrapa Western Region Agriculture, Dourados-MS, Brazil, 2012. 
suppressive effects depend both on the species grown in the winter and in the amount of straw left on the soil by these winter crops. Radish was more efficient in inhibiting the occurrence of weed species and rapeseed showed composition of infestation similar to that observed at the area under fallow.

\section{LITERATURE CITED}

BARBOUR, M. G. et al. Terrestrial plant ecology. Menlo Park: Benjamin/Cummings, 1998. 688 p.

BETTONI, J. C. et al. Potencial alelopático de plantas de cobertura verde de inverno sobre o crescimento do portaenxerto VR043-43. R. Ceres, v. 59, n. 1, p. 136-141, 2012.

BIANCHI, M. A. et al. Interferência de Raphanus sativus na produtividade de cultivares de soja. Planta Daninha, v. 29, n. 4, p. 783-792, 2011.

CECCON, G. Milho safrinha com braquiária em consórcio. Dourados: Embrapa Agropecuária Oeste, 2008. 6 p. (Comunicado Técnico, 140).

CHAMMOUN, N. Properties, performance, and economics of Raphanus sativus (oilseed radish) biodiesel. 2009. 63 f. Thesis (Master of Science) - University of Georgia, Athens, 2009.

CONAB. Acompanhamento da safra brasileira: grãos: safra 2010/2011: quarto levantamento: janeiro/2011. Brasília, DF, 2011. 41 p. Disponível em: <http://www.conab.gov.br/ OlalaCMS/uploads/arquivos/11_01_06_08_41_56_boletim_ graos_4o_lev_safra_2010_2011..pdf $>$. A Acesso em: 10 jun. 2012 .

CONCENÇO, G. et al. Soil seed bank of plant species as a function of long-term soil management and sampled depth.

Planta Daninha, v. 29, n. 4, p. 725-736, 2011.

CONTATO, E. D. Fitossociologia e períodos de convivência e de controle de plantas daninhas em soja transgênica. 2007. 36 f. Dissertação (Mestrado em Agronomia) - Universidade Estadual Paulista "Júlio de Mesquita Filho", Jaboticabal, 2007.

COSTEA, M.; WEAVER, S. E.; TARDIF, J. F. The biology of Canadian weeds. 130. Amaranthus retroflexus L., A. powellii S. Watson and A. hybridus L. Can. J. Plant Sci., v. 84 , n. 2 , p. $631-668,2004$

CRUZ, D. L. S. et al. Levantamento de plantas daninhas em área rotacionada com as culturas da soja, milho e arroz irrigado no cerrado de Roraima. Agroambiente, v. 3, n. 1, p. 58-63, 2009.

Planta Daninha, Viçosa-MG, v. 31, n. 3, p. 551-558, 2013
INDERJT; MALLIK, A. U. Chemical ecology of plants: allelopathy in aquatic and terrestrial ecosystems. Basel: Springer, 2002. $272 \mathrm{p}$

GOMES JUNIOR, F. G.; CHRISTOFFOLETI, P. J. Biologia e manejo de plantas daninhas em áreas de plantio direto. Planta Daninha, v. 26, n. 4, p. 789-798, 2008.

HEAP, I. The international survey of herbicide resistant weeds. [S.1.]: Weed Science, 2012. Disponível em: $<$ http:// www.weedscience.org/In.asp>. Acesso em: 11 maio 2012.

MESCHEDE, D. K.; FERREIRA, A. B.; RIBEIRO JUNIOR, C. C. Avaliação de diferentes coberturas na supressão de plantas daninhas no cerrado. Planta Daninha, v. 25, n. 3, p. 465-471, 2007.

MONSANTO apresenta Sistema Roundup Ready Plus para prevenção de plantas daninhas no Cerrado no Show Safra 2012. [S.1.]: Agromundo, 2012. Disponível em: <http://www. agromundo.com. $b r / ? p=23528>$. Acesso em: 11 maio 2012 .

PANDEYA, S. C.; PURI, G. S.; SINGH, J. S. Research methods in plant ecology. New York: Asia Publishing House, 1968. 272 p.

R DEVELOPMENT. R: A language and environment for statistical computing. Vienna: R Foundation for Statistical Computing, 2012. URL < http://www.R-project.org/> . Access in 10 Oct. 2012.

ROSSOL, C. D. et al. Levantamento fitossociológico de plantas daninhas na soja consorciada com braquiária. Cad. Agroecol., v. 6, n. 2, 2011. Disponível em: <http://www.abaagroecologia.org.br/ ojs2/ index.php/ cad/ article/ download/ 12683/ 7622>. Acesso em: 10 jun. 2012.

SILVA NETO, S. P. A evolução da produtividade da soja no Brasil. Planaltina, DF: Embrapa Cerrados, 2011. Disponível em: $<$ http://www.cpac.embrapa.br/ noticias/ artigosmidia/ publicados/335/>. Access in 11 may 2012

SNEATH, P. H.; SOKAL, R. R. Numerical taxonomy: the principles and practice of numerical classification. San Francisco: W. H. Freeman, 1973. 573 p.

SOKAL, R. R.; ROHLF, F. J. The comparison of dendrograms by objective methods. Taxon, v. 11, n. 1, p. 33-40, 1962.

TREZZI, M. M.; NUNES, A. L.; PORTES, E. S. Manejo de plantas daninhas através de métodos alternativos ao método químico. In: MARTIN, T. N.; MONTAGNER, M. M. (Ed.). Sistemas de produção agropecuária. Dois Vizinhos: UTFPR, 2007. p. 26-44.

UYGUR, F. N. et al. The allelopathic effect of Raphanus sativus L. J. Plant Pathol. Plant Protec., v. 12, p. 259-264, 1990. (Número Especial)

VOLLMANN, J.; WAGENTRISTL, H.; HARTL, W. The effects of simulated weed pressure on early maturity soybeans. Europ. J. Agron., v. 32, n. 4, p. 243-248, 2010. 